\title{
Hemşirelerin Hasta Teslimi İle İlgili Uygulamaları ve Görüşleri
}

\author{
Nurses' Practice and Opinions About Nursing Handover

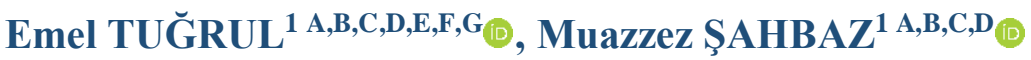 \\ ${ }^{1}$ Aydın Adnan Menderes Üniversitesi, Hemşirelik Fakültesi, Hemşirelik Esasları Anabilim Dalı, Aydın, Türkiye
}

ÖZ

\begin{abstract}
Amaç: Hasta teslimi hasta güvenliği çerçevesinde önemli bir yeri olan hemşirelik işlevlerinden biridir. Hasta teslimlerinin yanlış yapılandırılması advers (istenmeyen) olayların sıklı̆ııı artırmakta ve bakım kalitesini azaltmaktadır. Bu çalışma, hemşirelerin hasta teslimi ile ilgili uygulama ve görüşlerini belirlemek amacıyla yapılmıştır.

Yöntem: Analitik- kesitsel tipte olan araştırma, Aydın il merkezinde, Temmuz 2016 - Mart 2017 tarihleri arasında yataklı tedavi hizmeti veren dört hastanede hasta teslimi uygulanan kliniklerde çalışan 347 hemşire ile yapıldı. Çalışma verileri, hemşirelerin demografik ve mesleki bilgilerini, hasta teslimi ile ilgili uygulama ve görüşlerine yönelik soru formu ile toplandı. Araşsırmanın verileri; sayı, yüzde, aritmetik ortalama ve standart sapma değerleri ile yapıldı.

Bulgular: Araştırmaya katılan hemşirelerin yaş ortalamasının 31.0土9.01 olduğu, \%48.1'inin lisans mezunu olup, \%61.1'inin 0-12 yıldır görev yaptığı belirlendi. Hemşirelerin \%97.1'i hasta teslimlerinin yapılması gerektiğini, \%47.8'i hasta tesliminin yatak başında sözel, \%41.8'i yatak başında yazılı olması gerektiğini düşündüklerini ve \%80.4'ü hasta teslimi sırasında hasta yakınlarının odada bulunmasından rahatsız olduklarını bildirdi. Hemşirelerin \%64'ü hasta teslimlerini yatak başında sözel olarak yapııldığın, \%79.3'ü günde iki kez hasta teslimi yapıldığını ve ortalama 27-34 dakika sürdüğünü, \%66.9’u hasta teslimi için herhangi bir form kullanmadıklarını bildirdi. Hemşirelerin \%69.5'i hasta teslimini engelleyen en önemli faktörün iş yoğunluğu olduğunu, \%33.7'si hemşireler arasındaki iletişim eksikliğinin bu süreci etkilediğini ve \%80.4'ü teslim sırasında hasta yakınlarının ortamda bulunmasından rahatsız olduklarını bildirdi. Hemşireler hasta tesliminde aktarılması gereken bilgilerin hastanın mevcut durumunun ve günlük olarak takip edilmesi gereken bulguları olduğunu düşünmektedir.

Sonuç: Araşıtırma sonucunda; hemşirelerin hasta tesliminin yapılması gerektiğini ve yatak başında yapılan hasta tesliminin en etkili hasta teslim biçimi olduğunu düşündükleri belirlenmiştir. Hasta teslimlerinin süresinin ve teslim biçimlerinin kliniklere göre farklılık gösterdiği ve hasta tesliminin kaydedildiği yapılandırılmış bir form olmadığ belirlenmiş̧ir.
\end{abstract}

Anahtar Kelimeler: Hasta güvenliği, Hasta teslimi, Hemşire.

\section{ABSTRACT}

Objective: Nursing handover is one of the nursing functions that has an important role in patient safety. Misconfiguration of nursing handover increases the frequency of adverse events and reduces the quality of care. This study was carried out to determine nurses' practices and opinions about nursing handover.

Methods: This analytical-cross-sectional study was conducted with 347 nurses working in clinics where nursing handover was performed in four hospitals providing inpatient treatment services between July 2016 and March 2017 in Aydın city center. The study data were collected with a questionnaire regarding the demographic and professional information of nurses, their applications and opinions about patient delivery. The data of the research; number, percentage, arithmetic mean and standard deviation values were made.

Results: The mean age of the nurses participating in the study was $31.0 \pm 9.01,48.1 \%$ were university graduates and $61.1 \%$ had been working as nurses for $0-12$ years. $97.1 \%$ of the nurses reported that nursing handover should be made, $47.8 \%$ thought that nursing handover should be verbal at the bedside, $41.8 \%$ thought that should be written at the bedside and $80.4 \%$ of the nurses reported that they were uncomfortable with patient's relatives in the room during nursing handover. $64 \%$ of the nurses reported that nursing handover were made verbally at the bedside, $79.3 \%$ of the patients were delivered twice a day, and it took 27-34 minutes on average, and 66.9\% did not use any form for nursing handover. $69.5 \%$ of the nurses reported that the most important factor preventing the nursing handover was the work intensity, $33.7 \%$ of them stated that the lack of communication

Sorumlu Yazar: Emel TUĞRUL

Aydın Adnan Menderes Üniversitesi, Hemşirelik Fakültesi, Hemşirelik Esasları Anabilim Dalı, Aydın, Türkiye

emelturul@hotmail.com

Geliş Tarihi: 09.04.2020 - Kabul Tarihi: 03.09.2020

*Bu araştırma 26-28 Ekim 2018 tarihleri arasında Aydın'da düzenlenen Uluslararası Tarım Çevre ve Sağlık

Kongresinde sözel bildiri olarak sunulmuştur.

Yazar Katkıları: A) Fikir/Kavram, B) Tasarım, C) Veri Toplama ve/veya İşleme, D) Analiz ve/veya Yorum, E) Literatür

Taraması, F) Makale Yazımı, G) Eleştirel İnceleme 
between the nurses affected this process and $80.4 \%$ of the patients were disturbed by the presence of their relatives during the nursing handover. Nurses think that the information that should be conveyed in nursing handover is the current status of the patient and the findings that should be followed daily.

Conclusion: As a result of the research; It was determined that nurses think that nursing handover should be and the most effective nursing handover is bedside handover It was determined that the duration and forms of nursing handover differ according to clinics and there is no structured form in which nursing handover is recorded.

Key words: Nursing, Nursing handover, Patient safety.

\section{GíRiş}

Hasta teslimi, hastanın durumuna özgü özellikli bilgilerinin, bir sağlık profesyonelinden diğerine tam, doğru ve interaktif şekilde, standart bir iletişim tekniği kullanılarak devredildiği profesyonel bir iletişim süreci olarak tanımlanmaktadır (1). Hasta teslimi, sağlık alanında birçok sağlık profesyoneli tarafından kullanılmaktadır. Modern sağlık bakım sistemi çerçevesinde bu süreç, hasta bakımında özellikle hemşirelere önemli sorumluluklar yüklemektedir. Hasta teslimi kaliteli bakımın sağlanması, hemşirelik bakımının dökümante edilmesi ve hasta bilgilerinin hemşireler arasında doğru aktarılması konusunda önemli bir araçtır (2). Hemşireler arasındaki hasta teslimleri, hasta bilgilerinin ulaş1labilir olması, kaybolmaması, unutulmaması ve advers olayların azaltılmasında önemli bir yere sahiptir. Bunların yanında hasta teslimi, güvenli ve kaliteli bakımı desteklemede, bakımın sürekliliğini sağlamada ve hasta güvenliğinin artmasında büyük öneme sahiptir $(3,4)$.

Hasta teslim sürecinde; hasta bilgilerinin doğru, açık ve sistemli şekilde aktarılması sağlık profesyonelleri arasındaki iletişim ile mümkündür. Advers olayların, hataların ve neredeyse hataların çoğunun hasta teslimi sırasındaki iletişim eksikliğinden kaynaklandığı bildirilmiştir (5). Hasta teslim sürecinde iletişimdeki herhangi bir aksaklık, hastanın tanı/tedavi ve hastanede kalış süresinin uzamasına, hasta memnuniyetinin azalmasına ve maliyetin artmasına neden olmaktadır (4). Bu nedenle hasta teslim süreci, sağlık bakımı veren sağlık ekibinin tüm üyeleri ve hemşireler arasında aktif ve doğru iletişimi gerektirir. Hasta tesliminin uygulanma biçimi sağlı kurumlarında ve kliniklerde farklılıklar gösterebilmektedir. Hemşireler arasında hasta teslimi; nöbet değişimlerinde, kısa bir süre için personelin görev yerinden ayrıldığı durumlarda, hastanın transfer edildiği durumlarda, konsültasyon sürecinde, ameliyat öncesi ve sonrasında yapılmalıdır (6). Hasta tesliminin içeriği kliniklerin özelliklerine göre farklılık göstermektedir. Hasta tesliminin içeriğinde; hastanın durumu, tanımlayıcı verileri, mevcut sorunları, son tıbbi öyküsü, tedavileri ve alerjileri, laboratuvar verileri, beklenen sonuçlar, bakım planı ve herhangi bir psikolojik kaygı varlığını içeren bilgiler yer almalı, bu bilgiler açık, anlaşılır ve sistematik olmalıdır (4). Özellikle acil servisler ve yoğun bakım ünitelerinde bu içeriğe ek olarak kliniklerin durumuna göre farklı parametreler de eklenebilir (7).

Genel olarak hasta teslim biçimleri; sözel, yazılı, yatak başında, hemşire odasında ve hemşire deskinde yapılan hasta teslimleri olarak sınıflandırılabilir. Hasta teslim biçimlerinin her biri kliniklerin kendi koşulları dikkate alınarak uygulanmaktadır. Hasta teslim biçimine karar verirken, zaman faktörü, kliniğin fiziksel koşulları, hemşire ve hasta sayısı, vardiya saatleri gibi faktörler göz önünde bulundurulmalıdır. Ayrıca beklenen hasta sonuçları ve kurumun beklentileri de teslim biçiminin belirlenmesinde önemli rol oynamaktadır (8). Hasta teslim sürecinde, teslimin veriliş şekli ve yeri teslimin istenilen standartlarda olması ve bakımın kalitesi açısından önemlidir. Hasta güvenliği açısından ve teslimin etkinliğini artırmak için 
hasta tesliminin yatak başında yapılması önerilmektedir. Yatak başı teslim, hastayı görselleştirerek önceliklerin belirlenmesini, hastanın bakıma ve teslim sürecine aktif olarak katılmasını sağlamaktadır. Böylece hastalar kendilerini teslim sürecinin bir parçası olarak hissetmekte ve bu durum hastaların bakıma katılımlarını desteklemektedir $(9,10)$.

Hasta tesliminde bilgilerin yazılı olarak aktarılması önem taşımaktadır. Pothier ve arkadaşları çalışmalarında (2005), sadece sözel olarak yapılan hasta teslimlerinde birçok bilginin kaybolduğunu, unutulduğunu ve bazı bilgilerin önemsenmediğini ortaya koymuştur (11). Bu nedenle, son yıllarda birçok sağlık kurumunda hasta teslimi ile ilgili formlar kullanılmaya başlanmıştır. $\mathrm{Bu}$ formlar kliniklerdeki gereksinimlere göre ve hasta sınıflandırılmasına göre değişebilmektedir. Hasta tesliminde formların kullanılması, aktarılan bilgilerin kalıcı olmasını sağlamakla birlikte hemşireler için yasal bir doküman özelliği taşımaktadır. Ayrıca bu formlar, hastanın sağlık durumundaki değişiklerin gözden kaçmasını engellemekte ve hemşirelik bakım sürecini etkili hale getirmektedir $(12,13)$.

Hemşirelik bakımının kalitesinin artırılmasında, bakımın sürekliliğinin sağlanmasında ve hasta güvenliği açısından hasta teslimi önemli bir yere sahiptir. Ülkemizde sağlık kuruluşlarında hasta tesliminin yapıldığı bilinmesine rağmen bu konu ile ilgili yapılan çalışmaların yetersiz olduğu görülmüştür. Özellikle hasta teslim biçimleri hasta tesliminin içeriği ve hemşirelerin uygulamaları ile ilgili yapılan çalışmalara gereksinim olduğu düşünülmektedir. Bu nedenle bu çalışma hemşirelerin hasta teslimi ile ilgili uygulamalarını ve düşüncelerini belirlemek amacıyla yapılmıştır.

\section{Amaç}

Çalışmada, hemşirelerin hasta teslimi ile ilgili uygulamalarının ve düşüncelerinin belirlenmesi amaçlanmıştır.

\section{GEREÇ VE YÖNTEM}

Analitik-kesitsel bir çalışma olarak tasarlanan araştırma, Temmuz 2016 ile Mart 2017 tarihleri arasında Aydın merkezde bulunan üç devlet hastanesi ve bir üniversite hastanesinde olmak üzere toplam dört hastanede yürütülmüştür.

\section{Evren ve Örneklem}

Araştırmanın evrenini dört hastanede yataklı tedavi veren ve hasta tesliminin uygulandığ1 kliniklerde çalışan 1180 hemşire oluşturmuştur. Araştırmanın örneklemi, olasılıksız örnekleme yöntemi ile \%95 güven aralığında 290 olarak belirlenmiştir (14). Olası kayıplar göz önüne alınarak çalışmaya 347 hemşire dahil edilmiştir.

\section{Veri Toplama Araçları}

Verilerin toplanmasında literatür doğrultusunda araştırmacılar tarafindan hazırlanan soru formu kullanılmıştır $(2,8,15)$. Soru formu hemşirelerin demografik ve mesleki özelliklerini belirlemeye yönelik yedi, hasta teslimi ile ilgili uygulamalarma yönelik sekiz ve hasta teslimi ile ilgili düşüncelerine yönelik dokuz olmak üzere toplam 24 sorudan oluşmuştur.

Soru formunda; "Hasta tesliminin hasta başında olması sizi rahatsız eder mi?, " ve "Hasta teslimleri sırasında hasta yakınlarının odada bulunması sizi rahatsız eder mi?" sorularına 
evet cevabını veren hemşirelere rahatsız etme nedenleri açık uçlu soru olarak sorulmuş ve hemşirelerin açık uçlu sorulara vermiş olduğu cevaplar gruplandırılarak analiz edilmiştir.

\section{Araştırmanın Ön Uygulaması}

Çalışmada kullanılan veri toplama formunun anlaşılır olup olmadığını belirlemek için 10 hemşire ile ön uygulama yapılmıştır. Ön uygulama sonrasında hemşirelerin hasta teslimi ile ilgili düşünceleri bölümüne "Hasta teslimleri sırasında hasta yakınlarının odada bulunması sizi rahatsız eder mi?" ve "Rahatsız etme nedenleri nelerdir?" soruları eklenmiştir. Ön uygulamada yer alan hemşireler çalışmaya dâhil edilmemiştir.

\section{Verilerin Toplanması}

Veriler araştırmacılar tarafindan hemşirelerin gündüz çalışma saatleri olan 08.00 ile 16.00 saatleri arasında yüz yüze görüşme yöntemi ile toplanmıştır. Veri toplama öncesinde hemşirelere araştırmanın amacı açıklanmış ve gerekli bilgilendirme yapılmıştır. Veri toplama formunun uygulanması yaklaşık 15-20 dakika sürmüştür.

\section{Verilerin Değerlendirilmesi}

Araştırma verilerinin analizi bilgisayar ortamında ve SPSS istatistik paket programında (Version 22, Chicago IL, USA) gerçekleştirilmiştir. Sayısal değişkenlerde normal dağılıma uygunluk Shapiro-Wilk testi ile araştırılmış ve araştırma verilerinin normal dağılıma uygun olduğu belirlenmiştir. Araştırmanın verileri; sayı, yüzde, aritmetik ortalama ve standart sapma değerleri ile özetlenmiştir.

\section{Araştırmanın Etik Yönü}

Araştırmanın uygulanabilmesi için; Aydın Adnan Menderes Üniversitesi Tıp Fakültesi Girişimsel Olmayan Klinik Araştırmalar Etik Kurulu'ndan (25.12.2015 tarihli, 14083461/050.04-468 sayılı), Aydın Kamu Hastaneleri Birliği'nden, Aydın Adnan Menderes Üniversitesi Uygulama ve Araştırma Hastanesi Başhekimliğinden gerekli izinler alınmış ayrıca araştırma kapsamına alınan hemşirelere uygulamaya ilişkin bilgi verilerek sözlü onamları alınmıştır.

\section{BULGULAR}

Araştırmaya katılan hemşirelerin kişisel ve mesleki özellikleri incelendiğinde;

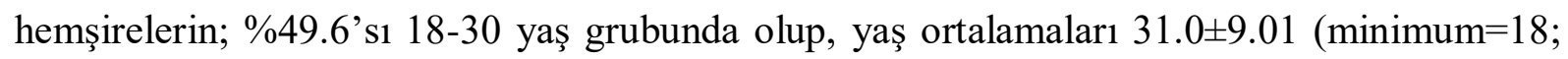
maksimum=55)' dir. Hemşirelerin \%92.5'i kadın, \%48.1'i lisans mezunu, \%61.1'inin çalışma süresi 0-12 yıl ve \%51'i üniversite hastanesinde ve \%47.3'ü yoğun bakımlarda çalışmaktadır. Ayrıca kurumlardaki yatak sayısı ortalaması $16.90 \pm 10.50$ ve hemşirelerin bakım verdikleri hasta sayısı ortalaması ise $7.31 \pm 5.81$ olarak belirlenmiştir (Tablo 1).

Hemşirelerin hasta teslimi ile ilgili uygulamalarının dağılımları incelendiğinde; hemşirelerin \%64'ü çalıştıkları kliniklerde hasta teslimlerinin yatak başında sözel olarak yapıldığını; \%79.3'ü hasta tesliminin günde iki kez yapıldığını ve \%48.7'si hasta teslimlerinin 27-43 dakika arasında sürdüğünü bildirmişlerdir. Hasta teslimlerinin ortalama süresinin ise $30.56 \pm 12.56$ dakika olduğu saptanmıştır. Hemşirelerin hasta teslimlerini kayıt altına alma durumlarına bakıldığında \%78.3'ü teslimleri kayıt altına aldığını, \%59.8'i hasta teslimi 
sırasında hastaların bilgilerini kayıt altına almak için boş bir kağıt kullandıklarını ifade etmişlerdir. Hemşirelerin \%81'i vardiya değişimlerinde nöbete gelen ve nöbetten çıkan hemşirelerin hepsinin tüm hastaların teslimine katıldıklarını belirtmişlerdir (Tablo 2).

Tablo 1. Hemşirelerin Demografik ve Mesleki Özellikleri

\begin{tabular}{|c|c|c|c|}
\hline Özellikler & Gruplar & $\mathbf{n}$ & $\%$ \\
\hline \multirow{3}{*}{ Yaş } & $18-30$ & 172 & 49.6 \\
\hline & $31-43$ & 138 & 39.7 \\
\hline & $44-55$ & 37 & 10.7 \\
\hline \multirow[b]{2}{*}{ Cinsiyet } & Kadın & 321 & 92.5 \\
\hline & Erkek & 26 & 7.5 \\
\hline \multirow{4}{*}{ Mezun Olduğu Okul } & Sağlik Meslek Lisesi & 73 & 21.0 \\
\hline & Ön Lisans & 92 & 26.5 \\
\hline & Lisans & 167 & 48.1 \\
\hline & Lisans Üstü & 15 & 4.4 \\
\hline \multirow{3}{*}{ Çalışma Süresi (yıl) } & $0-12$ & 212 & 61.1 \\
\hline & $13-25$ & 112 & 32.3 \\
\hline & $26-37$ & 23 & 6.6 \\
\hline \multirow{4}{*}{ Çalıştığı Hastane } & Devlet Hastanesi & 85 & 24.5 \\
\hline & Üniversite Hastanesi & 177 & 51.0 \\
\hline & Atatürk Devlet Hastanesi & 35 & 10.1 \\
\hline & $\begin{array}{l}\text { Kadın Doğum ve Çocuk } \\
\text { Hastalıkları Hastanesi }\end{array}$ & 50 & 14.4 \\
\hline \multirow[t]{3}{*}{ Çalıştığı Klinik } & Yoğun Bakım & 164 & 47.3 \\
\hline & Cerrahi Klinikler & 97 & 27.9 \\
\hline & Dâhili Klinikler & 86 & 24.8 \\
\hline \multicolumn{4}{|c|}{$\begin{array}{l}\text { Kliniklerdeki yatak sayısı } \\
\text { Ort }=16.90 \pm 10.50\end{array}$} \\
\hline \multicolumn{4}{|c|}{$\begin{array}{l}\text { Bakım verilen hasta sayısı } \\
\text { Ort }=7.31 \pm 5.81\end{array}$} \\
\hline TOPLAM & & 347 & 100.0 \\
\hline
\end{tabular}

Ort= Ortalama değer

Hemşirelerin hasta teslimi ile ilgili düşüncelerinin dağılımları incelendiğinde; hemşirelerin \%97.1'i hasta tesliminin yapılması gerektiğini, \%48.7'si hasta tesliminin yatak başında sözel, \%48.1'i yatak başında yazılı olmasını, \%93.1'i hasta tesliminin yatak başında olmasından rahatsızlık duymadıklarını, \%80.4'ü ise hasta teslimi sırasında hasta yakınlarının odada bulunmasından rahatsız olduklarını ve tümü hasta tesliminde bir form kullanılması gerektiğini belirtmişlerdir (Tablo 3). Hemşireler hasta teslim formunda, hastanın kimlik bilgilerinin, tıbbi tanısının, alerji bilgilerinin, yaşam bulgularının, kullandığ 1 ilaçların, intravenöz kateter durumunun, aldığı intravenöz sıvıların, aldığı-çıkardığı sıvı dengesi bilgilerinin, düşme risk puanının, yatak yarası risk puanının olması gerektiğini düşünmektedir. Hemşireler ayrıca, hasta ile ilgili bazı bilgilerin farklı formlarda yer aldığını ve bu nedenle ayrıca hasta teslim formunda olmasının gereksiz olduğunu düşündüklerini bildirmişlerdir.

Hasta tesliminin yatak başında sözel olması gerektiğini bildiren hemşireler; yatak başı hasta teslimi yapıldığında, hastalar ile iletişime geçerek bilgi alabileceklerini, bakımın sürekliliğini sağlayacağını, hastanın bütüncül değerlendirilebileceğini, hastanın daha iyi tanınmasını sağlayacağını ve daha iyi gözlem yapılabileceğini belirtmişlerdir. Hasta tesliminin yatak başında yazılı olarak yapılması gerektiğini düşünen hemşireler; bilgilerin kalıcı olacağını, yasal bir kanıt olarak kullanılacağını, bilgilerin eksiksiz verilmesini sağlayacağını, aktarılan bilgilerin unutulmasını engelleyeceğini, hasta ile ilgili ayrıntılı bilgilerin atlanmayacağını, daha 
Tablo 2. Hemşirelerin hasta teslimi ile ilgili uygulamaları

\begin{tabular}{|c|c|c|}
\hline Uygulamalar & $\mathbf{n}$ & $\%$ \\
\hline \multicolumn{3}{|l|}{ Hasta Teslim Biçimleri } \\
\hline Yatak Başında Sözel & 222 & 64.0 \\
\hline Yatak Başında Yazılı & 73 & 21.0 \\
\hline Hemşire Odasında Sözel & 31 & 8.9 \\
\hline Hemşire Odasında Yazılı & 16 & 4.6 \\
\hline Yatak Başında Sözel, Hemşire Odasında Yazılı & 5 & 1.5 \\
\hline \multicolumn{3}{|l|}{ Hasta Teslimi Sıklığı } \\
\hline Günde 1 & 19 & 5.4 \\
\hline Günde 2 & 275 & 79.3 \\
\hline Günde 3 & 44 & 12.7 \\
\hline Günde 4 ve fazla & 9 & 2.6 \\
\hline \multicolumn{3}{|l|}{ Hasta Teslim Süresi/dakika } \\
\hline $10-26 \mathrm{dk}$ & 107 & 30.8 \\
\hline $27-43 \mathrm{dk}$. & 169 & 48.7 \\
\hline $44-60 \mathrm{dk}$ & 71 & 20.5 \\
\hline \multicolumn{3}{|l|}{ Hasta Teslimi kayıt durumu } \\
\hline Ediliyor & 272 & 78.3 \\
\hline Edilmiyor & 75 & 21.7 \\
\hline \multicolumn{3}{|l|}{ Kayıt İșlemi $(n=272)$} \\
\hline Kayıt İçin Standart Form & 26 & 9.7 \\
\hline Hemşire Gözlem Formu & 79 & 29.1 \\
\hline Boş Not Kâğ $1 d_{1}$ & 162 & 59.8 \\
\hline Hasta Listesi & 5 & 1.4 \\
\hline \multicolumn{3}{|l|}{ Hasta Teslimine Katılma Biçimi } \\
\hline Tüm Hemşireler Bütün Hastaların Teslimine Katılır. & 281 & 81.0 \\
\hline $\begin{array}{l}\text { Her Hemşire Sadece Bakım Verdiği/Vereceği Hastaların } \\
\text { Teslimine Katılır. }\end{array}$ & 66 & 19.0 \\
\hline Toplam & 347 & 100 \\
\hline
\end{tabular}

Tablo 3. Hemşirelerin Hasta Teslimi İle İlgili Düşünceleri

\begin{tabular}{|c|c|c|}
\hline Görüşler & $\mathbf{n}$ & $\%$ \\
\hline \multicolumn{3}{|l|}{ Hasta Teslimi yapılmalı mı? } \\
\hline Evet & 337 & 97.1 \\
\hline Hayır & 10 & 2.9 \\
\hline \multicolumn{3}{|l|}{ Hasta Teslim Biçimleri Nasıl Olmalı? } \\
\hline Yatak Başında Sözel & 169 & 48.7 \\
\hline Yatak Başında Yazılı & 145 & 41.8 \\
\hline Hemşire Odasında Sözel & 17 & 4.9 \\
\hline Hemşire Odasında Yazılı & 7 & 2.0 \\
\hline Yatak Başında Sözel, Hemşire Odasında Yazılı & 9 & 2.6 \\
\hline \multicolumn{3}{|c|}{ Hasta tesliminin yatak başında olması sizi rahatsız eder mi? } \\
\hline Evet & 14 & 6.9 \\
\hline Hayır & 323 & 93.1 \\
\hline \multicolumn{3}{|c|}{$\begin{array}{l}\text { Hasta teslimi sırasında hasta yakınlarının odada bulunması sizi } \\
\text { rahatsız eder mi? }\end{array}$} \\
\hline Evet & 279 & 80.4 \\
\hline Hayır & 68 & 19.6 \\
\hline \multicolumn{3}{|l|}{ Hasta Teslim Formu kullanılmalı mı? } \\
\hline Evet & 347 & 100 \\
\hline Hayır & - & - \\
\hline Toplam & 347 & 100 \\
\hline
\end{tabular}


güvenilir olacağını ve olabilecek hataları azaltacağını düşündüklerini bildirmişlerdir. Hasta tesliminin yatak başında yapılmasından rahatsızlık duyan ve hemşire odasında yapılması gerektiğini düşünen hemşireler bunun nedeni olarak, hastaların aktarılan bilgileri yanlış anlayabileceğini, kargaşa olduğunu ve teslimlerin çok uzun sürdüğünü, hastaların tedavi ve bakım ile ilgili bilgileri duymalarının gereksiz olduğunu ve aktarılan bazı bilgilerden hastaların rahatsız olabileceğini düşündüklerini bildirmişlerdir.

Hemşirelerin \%80.4'ü hasta teslimi sırasında hasta yakınlarının ortamda bulunmasından rahatsızlık duyduklarını bildirmişlerdir. Rahatsızlık duymalarının nedenleri olarak; hasta teslimi sırasında sürekli müdahale edildiğini, ortamda gürültü olduğunu, hastaların mahremiyetini etkilediğini, teslim sırasındaki hasta yakınlarının konuşmaları yanlış anladıklarını ve sürekli ve gereksiz soru sorduklarını, dikkat dağınıklığına neden olduklarını, duydukları nedeniyle hasta yakınlarının endişelendiğini, teslimin sürekli kesintiye uğradığını ve hasta tesliminin süresini uzattığını düşündüklerini belirtmişlerdir.

Hemşireler hasta teslimini engelleyen durumların; çalışma saatlerinde iş yoğunluğunun fazla olması (\%69.5), gürültü (\%60.5), hasta ile ilgili bilgi eksikliği (\%60.5), hemşirelik dış1 görevlerin olması (\%43.2), bakım verilen hasta sayısının fazla olması (\%39.2), hemşireler arasındaki iletişim problemleri (\%33.7), hasta tesliminde zamanın kısıtlı olması (\%24.8) ve bilgilerin yanlış aktarılması (\%15.0) olduğunu bildirmişlerdir. Hemşireler hasta tesliminde yaşanan diğer problemler arasında; hekim vizitlerinin hasta teslimini bölmesi, evraklarda eksiklik olması, vardiya değişimlerinde hemşirelerin mesaiye geç kalması ve hasta teslimlerinin bir an önce bitirilmek istenmesi yüzünden bilgilerin yüzeysel olarak aktarılması gibi problemlerin yaşandığını bildirmişlerdir (Tablo 4).

Tablo 4. Hasta Teslimini Engelleyen Durumlar

\begin{tabular}{lcc}
\hline Engelleyen Durumlar ${ }^{*}$ & n & \% \\
\hline İş Yoğunluğu & 241 & 69.5 \\
Gürültü & 210 & 60.5 \\
Hasta İle İlgili Bilgi Eksikliği & 210 & 60.5 \\
Hemşirelik Dışındaki Görevler & 150 & 43.2 \\
Hasta Sayısının Fazla Olması & 136 & 39.2 \\
Hemşireler arasındaki iletişim problemleri & 116 & 33.7 \\
Zamanın Kısıtlı Olması & 86 & 24.8 \\
Bilgilerin yanlış aktarılması & 52 & 15.0 \\
Diğer Problemler & 51 & 14.8 \\
\hline${ }^{* B i r d e n ~ f a z l a ~ s e c ̧ e n e k ~ i s ̧ a r e t l e n m i s ̦ t i r . ~}$ & &
\end{tabular}

\section{TARTIŞMA}

Hemşirelerin gün içindeki temel işlevlerinden biri olan hasta teslimleri hemşirelik bakım kalitesinin yükseltilmesinde ve hasta güvenliğinde önemli bir yere sahiptir. Etkili bir hasta teslimi hemşireler arasında iletişimin sürdürülmesini ve hasta bilgilerinin hemşireler arasında doğru aktarılmasını sağlayan aktif bir süreçtir. Hasta tesliminin hasta güvenliği çerçevesinde değerlendirilmesi gerektiği, hemşireler arası etkili iletişimin artırılmasının önemi ve hasta bilgilerinin doğru aktarılmasının advers olayları azaltabileceği vurgulanmaktadır (16). Tüm bunlara ek olarak hasta teslimi, bakımın sürekliliğinin sağlanmasında, tekrarların azalması ve hasta memnuniyetinin artmasında etkili olup ayrıca işe yeni başlayan personelin ve öğrenci hemşirelerin eğitimi için de firsat sunmaktadır (17). Çalışmamıza katılan hemşirelerin \%97.1'i hasta tesliminin yapılması gerektiğini düşünürken tümünün hasta teslimini yaptığı 
belirlenmiştir. Bu sonuç; çalışmaya alınan hemşirelerin bazılarının hasta teslimine gerek olmadığını düşündüklerini belirtmelerine rağmen, tüm hemşireler tarafindan hasta tesliminin yapılıyor olması kurumların bu konuya verdiği önemi göstermektedir.

Çalışmamızda hemşirelerin çoğunluğunun hasta teslimini yatak başında sözlü (\%64) ya da yazılı (\%21) olarak gerçekleştirdikleri saptanmış, aynı şekilde hemşirelerin büyük çoğunluğunun hasta tesliminin yatak başında yazılı (\%48.7) ya da sözlü (\%41.8) olarak yapılması gerektiğini düşündüklerini belirtmişlerdir. Bunun nedeni olarak hasta tesliminin yatak başında yapılmasının; hastayı gözlemleme firsatı sağlaması, hastalardan direk bilgi alınabilmesi, bakımın sürekliliğinin sağlanması, hastanın bütüncül değerlendirilmesi, hastanın daha iyi tanınması ve daha iyi gözlem yapılabilmesi açısından diğer teslim türlerine (hemşire deski, hemşire odası, ses kaydı) göre daha etkin olduğunu bildirmişlerdir. Literatürde de yatak başı hasta teslimi ile hastanın daha iyi gözlendiği ve hastanın durumu ile ilgili bilgilerin daha doğru aktarıldığı belirlenmiştir (18). Hasta teslimi hastayı görselleştirerek önceliklerin belirlenmesini, hastanın bakıma ve teslim sürecine aktif olarak katılmasını, hastanın kendini önemli hissetmesini (19) sağlamasının yanında hasta ve hemşire arasındaki iletişimin gelişmesine firsat vermektedir (10,20). Yatak başı hasta teslim şeklinin; bakımın sürekliliğini sağlaması, hastanın durumunu daha iyi açıklaması, hastaların ve hasta yakınlarının kendilerini daha güvende hissetmesi (17), hastayla ilişkili önemli durum ya da sorunları hatırlatması, bakım planının daha iyi yapılandırılmasını sağlaması (21) gibi birçok olumlu yönü bulunmaktadır. Çalışmamıza katılan hemşirelerin hasta tesliminin neden yatak başında yapılması gerektiği ile düşünceleri literatür bilgisi ile benzerlik göstermektedir.

Hasta tesliminin yatak başında yapılmaması gerektiğini düşünen hemşireler bunun nedeni olarak, yatak başı hasta tesliminin çok fazla zaman aldığını ve vardiya sonrası hemşirelerin uzun bir süre daha klinikte kalmasının gerektiğini bildirmişlerdir. Bunun yanında hastalar açısından bakıldığında ise, hastaların aktarılan bilgileri yanlış anlayabileceği, hastaların tedavi ve bakım ile ilgili bilgileri duymalarının gereksiz endişeye neden olabileceği ve kendileri ile ilgili bazı bilgileri yakınları ya da hasta odasındaki diğer hastaların duymalarından rahatsızlık duyabileceklerini ifade etmişlerdir. Wakefield (2012) çalışmasında; hasta teslimi yatak başında yapıldığında hemşirelerin daha fazla zaman harcadığı, teslim süresi uzadıkça kesintilerin arttı̆̆ 1 ve klinikteki diğer işlerin aksadığını bildirmişlerdir (22). Yapılan benzer bir çalışmada da hastalar, hasta teslimi sırasında kendileri hakkındaki bilgilerin hasta yakınları ve odada bulunan diğer hastalar tarafından duyulmasını istemediklerini ve bu durumdan rahatsız olduklarını belirtmişlerdir (23). O'Connell ve Penney (2001) çalışmalarında, hemşirelerin yatak başı teslim konusunda hastaların gizlilik ve mahremiyetinin ihlal edilebileceği endişesi taşıdıklarını özellikle çok yataklı odalarda duyarlı ve hassas paylaşımlar yapılmasının gerektiğini ve dikkatsiz konuşmaların hastaların güvenine zarar verebileceğini ifade etmişlerdir (24). Lupieri ve arkadaşlarının (2015) hemşirelerin yatak başı hasta teslimi ile ilgili düşüncelerini belirledikleri çalışmalarında; katılımcıların çoğu yatak başı teslimin pozitif ve daha etkili olduğunu düşünseler bile, teslim sırasında hastaların teslimin içeriğini dinlerken hemşirelerin dikkatini toplayamadığını, hastaların bazı sorularına yanıt veremediklerini, hasta ile ilgili düşüncelerini hastalara söylemediklerini, hastalar ile ilgili kötü bir gelişme olduğunda yatak başında konuşmalarının hastaların daha fazla üzülmelerine neden olduğunu belirlemişlerdir (9). Çalışmamıza katılan hemşirelerin hasta tesliminin yatak başında 
yapılmaması gerektiği ile ilgili düşünceleri yapılan çalışmalarla ve literatür bilgisi ile benzerlik göstermektedir.

Literatürde hasta teslim biçimlerinden hangisinin en etkin teslim biçimi olduğuna dair bir kanıt bulunmamasına rağmen, hemşireler arasında yatak başında yapılan hem yazılı hem sözlü teslimin daha çok tercih edildiği (11), hemşire deskinde/odasında ya da kayıtla yapılan sözel teslimlerin ise, hasta bilgilerinin yanlış/eksik aktarılması ve unutulması gibi problemlere yol açtığ

Çalışmamıza katılan hemşirelerin \%64'ü hasta teslimini sözlü olarak yaptıklarını belirtmişlerdir. Hasta teslim biçimi ile ilgili düşünceleri incelendiğinde, \%48.7'sinin hasta tesliminin sözlü, \%41.8'inin ise yazılı olarak yapılması gerektiğini düşündükleri belirlenmiştir. Hasta tesliminin yazılı yapılmasının gerekliliğini düşünen hemşireler yazılı yapılan hasta tesliminde hasta ile ilgili veri kaybı olmayacağını, bilgilerin kalıcı olacağını ve kanıt niteliği taşıyacağını belirtmişlerdir. Hasta tesliminin sözlü olarak yapılmasını düşünen hemşireler ise hasta tesliminin yazılı olarak yapılmasının zaman kaybına neden olduğunu, bu nedenle sözlü teslimi tercih ettiklerini belirtmişlerdir. Pothier ve arkadaşları (2005), sözel teslim, kayıtlardan yapılan teslim ve yatak başı teslim türlerini karşılaştırdıkları çalışmalarında sadece sözel yolla yapılan teslimlerin genellikle gereksiz bilgileri de içerebileceğinden ve hastaya ait bilgilerin tamamının akılda tutulması güç olacağından veri kaybı olma olasılığının diğer teslim çeşitlerine göre daha fazla olduğunu saptamışlardır (11). Pothier ve arkadaşlarının çalışma sonuçları ile çalışmamızda elde edilen sonuçlar benzerlik göstermektedir. Çalışmamızda hasta tesliminin sözlü olarak yapılması gerektiğini düşünen hemşire sayısının, hasta teslimini sözlü olarak uygulayan hemşire sayısından daha az olması düşündürücü bir sonuçtur. Hastane protokolleri, hemşirelik dışı görevler, zaman azlığı, iş yükünün fazla olması gibi nedenlerden dolayı hemşirelerin yazılı teslimin gerekliliğine inanmalarına rağmen sözlü teslimi tercih ettikleri düşünülebilir. Ülkemizde 2011 yılında Sağlık Bakanlığı Performans Yönetimi Kalite Geliştirme Daire Başkanlığ 1 tarafından yayınlanan hastane hizmet kalite standartlarında da hasta tesliminin önce hemşire deskinde daha sonra yatak başında yazılı/sözlü yapılması gerektiği belirtilmiştir (26).

Çalışmamızda hasta teslimlerinin \%48.7'sinin 27-43 dakika sürdüğü, en kısa hasta tesliminin 10 dakika ve en uzun hasta tesliminin ise 60 dakika sürdüğü belirlenmiştir. Hasta tesliminin süresi, hasta sayısına ve hastaların durumuna göre farklılık gösterebilir. Literatürde hasta tesliminin ortalama 15-30 dakika sürdüğü bildirilmektedir (27). Alvarado ve arkadaşları (2006) yaptıkları çalışmada, acil durumlarda teslim süresinin hasta başına en çok altı dakika, en az bir-iki dakika sürdüğünü bildirmişlerdir (28). Mosher ve Bontomasi (1996) ise komplike hastaların bir teslimin ortalama 45-50 dakikada tamamlandığını bildirmişlerdir (29). Yoğun bakım ünitelerinde yapılan başka bir çalışmada ise hemşirelerin \% 73.7'si hasta teslimlerinin 30 dakikadan az, \%26.3'ü ise 31-60 dakika sürdüğünü bildirmişlerdir (30). Uzun süren hasta teslimlerinin çoğunun komplike hastaların bulunduğu yoğun bakım ünitelerinde olduğu tespit edilmiştir. Çalışma sonucumuz konu ile ilgili yapılan diğer çalışma sonuçları ile benzerlik göstermektedir.

Çalışmamızda hemşirelerin çoğunluğu hasta tesliminde kurum tarafindan belirlenmiş standart bir form kullanmadıklarını genellikle teslim sırasındaki bilgileri klinikte kullandıkları diğer formlara, kendilerinin oluşturdukları çizelgelere ya da boş bir kâğıda kaydettiklerini bildirmişlerdir. Sert ve arkadaşlarının (2019) yoğun bakım hemşireleri ile yaptıkları çalışmada, 
hemşirelerin \%65'inin standart hasta teslim formu oluşturulması gerektiğini düşündüklerini bildirmişlerdir (30). Yapılan çalışmalar hasta teslimi için harcanan zamanın azalması ve aktarılan bilgilerin tam ve eksiksiz olması için standart kayıt formlarının kullanılmasını ve bu kayıtların elektronik kayıt sistemine aktarılmasının gerektiğini vurgulamaktadır (31-33). Hasta tesliminde bilgilerin doğru, eksiksiz, unutulmadan, iletişim problemi olmadan aktarılması ve zaman kaybının en aza indirilmesi için hastanelerde standart bir hasta teslim formu oluşturulmalıdır. Oluşturulan bu formlar hizmet içi eğitimlerle hemşirelere anlatılarak hasta tesliminde standart bir dil oluşturulabilir.

Hemşireler hasta teslim formunda hasta bilgilerinin; tıbbi tanısı, alerji bilgileri, yaşam bulguları, aldığı çıkardığı sıvı izleminin, intravenöz kateter durumunun, intravenöz sıvılarının, düşme risk puanının, basınç ülseri risk puanı gibi bilgilerin olması gerektiğini bildirmişlerdir. Toeima ve Morris'e (2013) göre hasta teslim formu, hastanın durumu ve verilerinin tanımlanması, tıbbi öyküsü, mevcut sorunları, ilaçları, alerjileri, laboratuvar verileri, bakım planını etkileyecek herhangi bir psikososyal kaygı varlığı gibi bilgileri içermelidir (4). Matic, Davidson ve Salamanson (2011) ise; takip edilmesi gereken drenler, göğüs tüpü, oksijen satürasyonu ve santral venöz basınç takibi gibi parametrelerin de hasta tesliminde aktarılan bilgiler arasında olması gerektiğini belirtmişlerdir (13). Welsh ve arkadaşları (2010) yaptıkları çalışmada, hasta teslim formlarının tedavi ve yaşam bulgularını, laboratuvar sonuçlarını, hastanın oryantasyonu, mobilizasyon durumunu içeren her birime özgü olarak geliştirilmiş formlar olması gerektiğini bildirmişlerdir (34). Çalışma sonucumuz yapılan çalışmalarla ve literatür bilgileri ile benzerlik göstermesine rağmen, çalışmamızda hasta teslim formunda hasta ile ilgili bulunması gereken bilgiler genellikle hastanın fizyolojik durumu, takip ve tedavileri, yaşam bulguları gibi bilgileri içerirken hastanın psikososyal ve kültürel boyutu ile ilgili bilgilere değinilmemiştir. Buradan yola çıkarak hasta teslimi için hazırlanan standart formlarda hastanın psikososyal ve kültürel özelliklerinin de yer alması gerektiği önerilebilir.

Çalışmamızda, hemşirelerin \%81'i vardiya değişiminde yapılan hasta teslimlerine, servis sorumlu hemşiresinin, hastaya bakım veren ve nöbeti devir alan hemşirelerin katıldığını bildirmişlerdir. Avustralya hasta bakım kalitesi ve güvenliği komisyonu (2009) yayınladığ klinik hasta teslimi rehberinde teslime katılması gereken kişileri; servis sorumlu hemşiresi, hastaya bakım veren hemşire ve nöbeti devir alan hemşire ve vardiya sorumlusu hemşire olarak belirtmiştir (35). Çalışmamızda hemşirelerin çoğunluğunun bu rehbere uygun olarak teslime katıldıkları görülmektedir.

Hemşirelerin \%33.7'si hemşireler arasındaki iletişim problemlerinin hasta tesliminde önemli sorunlara neden olduğunu bildirmişlerdir. Hasta teslimi sırasındaki iletişimsizlik; tıbbi hatalara, hizmetin aksamasına, gereksiz bilgi aktarımlarına, hasta izlem sistemlerinin daha fazla kullanılmasına ve hasta memnuniyetsizliğine yol açabilir $(3,28,33)$. Çalışma sonucumuza göre hemşireler arasında iletişim problemlerinin yüksek olduğu görülmektedir. Bu durum hasta tesliminin etkin ve güvenilir bir şekilde yapılmasını engelleyebilir. Bu nedenle hemşireler arasındaki iletişim problemlerinin nedenleri araştırılmalı ve bu problemlerin giderilmesine yönelik çalışmalar yapılmalıdır. Bunun yanında hasta tesliminde iletişim eksikliklerini gidermeye yönelik etkin iletişim tekniklerini içeren sistematik bir yaklaşım ya da model kullanılabilir.

Hemşirelerin hasta tesliminde karşılaştıkları sorunlar arasında; iş yoğunluğunun fazla olması, ortamdaki gürültü, hasta ile ilgili bilgi eksiklikleri, hemşirelerden farklı görevlerin 
beklenmesi, bakım verilen hasta sayısının fazlalığı ve hasta tesliminde zamanın kısıtlı olması gibi sorunlar yer almaktadır. Hemşireler hasta tesliminde hekim vizitlerinin hasta teslimini bölmesi, evraklarda eksiklik olması, vardiya değişimlerinde hemşirelerin mesaiye geç kalması ve hasta teslimlerinin bir an önce bitirilmek istenmesi yüzünden bilgilerin yüzeysel olarak aktarılması gibi problemlerin yaşandığını da bildirmişlerdir. Toeima ve Morris (2013), hemşirelerin zaman kısıtlılığı ve iş yükünün fazla olmasına bağlı olarak hasta tesliminde bilgilerin kısa sürede aktarılmaya çalışılmasının, bilgilerin kaybolması, unutulması ve iletilememesi gibi problemlere yol açtığını bildirmişlerdir (4). Manser ve Foster (2011), hasta teslimi sirasında hastane ortamındaki kalabalıktan ve kullanılan cihazlardan kaynaklanan gürültünün hasta teslimlerinin kalitesini etkilediğini saptamışlardır (20). Davies ve Priestly çalışmalarında (2006); hasta teslimlerinde gereksiz ve ilgisiz bilgilerin yer alması, bilgilerin hızlı aktarılmaya çalışılması, teslim sırasında belirsiz ifadelerin kullanılması ve hafızaya dayalı güvenilir olmayan bilgilerin verilmesi gibi problemlerin yaşandığını belirlemişlerdir (25). Yapmış olduğumuz çalışmada hasta teslimini engelleyen durumların yapılan diğer çalışmalarda saptanan durumlarla benzer olduğu söylenebilir.

\section{SONUÇ VE ÖNERILER}

Sonuç olarak, hemşirelerin çoğunluğunun hasta teslimini yatak başında sözlü olarak yaptıkları, hasta tesliminin yapılması gerektiğini ve en etkili hasta teslim biçiminin yatak başında yazılı/sözlü yapılan hasta tesliminin olduğunu düşündükleri belirlenmiştir. Çalışmaya katılan hemşirelerin çoğu hasta tesliminin yatak başında olmasından rahatsızlık duymazken hasta teslimi sırasında hasta yakınlarının olmasından rahatsızlık duyduklarını belirtmişlerdir.

Hemşirelerin tümü hasta tesliminin kaydedilmesinin önemli olduğunu ve kayıt için bir form kullanılması gerektiğini bildirmelerine rağmen büyük çoğunluğu teslim sırasında bilgileri boş bir kâğıda not ettiklerini hasta teslimi için standart formlarının olmadığını bildirmişlerdir. Hastane ortamında hasta teslimini etkin bir şekilde yapılmasını engelleyen durumlar arasında fiziki ortamdan kaynaklanan problemlerin yanı sıra, hemşirelerin iş yoğunluğu, iletişim sorunları, zaman kısıtlılığı gibi faktörlerin de yer aldığı görülmektedir. $\mathrm{Bu}$ sonuçlar doğrultusunda, ülkemizde kalite ve hasta güvenliği çerçevesinde, hasta teslimi ile ilgili standartların belirlenmesi, kliniklere özgü hasta teslim biçimlerinin geliştirilmesi, hemşirelere bu konuda eğitim verilmesi ve hasta tesliminde kullanılacak standart formların geliştirilmesi, hasta teslimi yapılan diğer birimlerde (acil servis, ambulans hizmetleri vb.) benzer çalışmaların yapılması ve konu ile ilgili gözlemsel çalışmaların yapılması önerilebilir.

\section{Sinırlılıklar}

Çalışmanın hastanelerin sadece yataklı tedavi hizmeti veren kliniklerinde yapılması, verilerin araştırmacılar tarafından 08.00-16.00 saatleri arasında toplanması nedeniyle sürekli gece vardiyasında çalışan hemşirelere ulaşılamaması çalışmanın sınırlılıkları olarak verilebilir.

\section{Araştırmanın Etik Yönü}

Araştırmanın uygulanabilmesi için; Aydın Adnan Menderes Üniversitesi Tıp Fakültesi Girişimsel Olmayan Klinik Araştırmalar Etik Kurulu'ndan (25.12.2015 tarihli, 
14083461/050.04-468 sayıl1), Aydın Kamu Hastaneleri Birliği'nden, Aydın Adnan Menderes Üniversitesi Uygulama ve Araştırma Hastanesi Başhekimliğinden gerekli izinler alınmış ayrıca araştırma kapsamına alınan hemşirelere uygulamaya ilişkin bilgi verilerek sözlü onamları alınmıştır.

\section{Çıkar Çatışması}

Yazarlar arasında çıkar çatışması yoktur.

\section{KAYNAKLAR}

1. Piekarski, F., Kaufmann, J., Laschat, M., Böhmer, A., \& Engelhardt, T. (2015). Quality of handover in a pediatric postanesthesia care unit. Pediatric Anesthesia, 25(7), 746752.

2. Nursing handover for adult patients guidelines. NHS Wales Informatics Service 2008. http://www.wales.nhs.uk/sitesplus/documents/ (Erişim tarihi: 15.10.2019).

3. McMurray, A., Chaboyer, W., Wallis, M., Johnson, J., \& Gehrke, T. (2011). Patients' perspectives of bedside nursing handover. Collegian, 18, 19-26.

4. Toeima, E., \& Morris, E. (2013). Improving patients' handover. Obstet Gynaecol Reprod Med, 23(7), 221-23.

5. Jagsi, R., Kitch, B.T., Weinstein, D.F., Campbell, E.G., Hutter, M., \& Weissman, J.S. (2005). Residents report on adverse events and their causes. Arch Intern Med, 165(22), 2607-13.

6. Smeulers, M, Tellingen, IC., \& Lucas, C. (2012). Effectiveness of Different Nursing Handover Styles For Ensuring Continuity Of İnformation İn Hospitalised Patients (Protocol). The Cochrane Library, 7, 1-12.

7. Randell, R., Wilson, S., \& Woodward, P. (2011). The importance of the verbal shift handover report: a multi-site case study. Int J Med Inform., 80 (11), 803-12.

8. Lockwood, C. (2016). What is the best nursing handover style to ensure continuity of information for hospital patients? Int J Nurs Stud., 58, 97-99.

9. Lupieri, G., Creatti, C., \& Palese, A. (2016). Cardio-thoracic surgical patients' experience on bedside nursing handovers: Findings from a qualitative study. Intensive Crit Care Nurs., 35, 28-37.

10. Rifai, A., Afandi, A.T., \& Hasanah, A. (2019). Bedside Nursing Handover: Patient's Perspective. Nurseline Journal, 4(2), 123-130.

11. Pothier, D., Monteiro, P., Mooktiar, M., \& Shaw, A. (2005). Pilot study to show the loss of important data in nursing handover. Br J Nurs., 14 (20), 1090-3.

12. Halterman, R.S., Gaber, M., Janjua, M.S.T., Hogan, G.T., \& Cartwright, S.M.I. (2019). Use of a checklist for the Postanesthesia Care Unit Patient Handoff. J Perianesth Nurs, 34(4), 834-41.

13. Matic, J., Davidson, PM., \& Salamonson, Y. (2011). Review: bringing patient safety to the forefront through structured computerisation during clinical handover. J Clin Nurs., 20 (1-2), 184-189.

14. Karasar, N. (2005). Bilimsel araştırma yöntemi: kavramlar, ilkeler, teknikler. Ankara: Nobel Yayın Dağıtım.

15. Johnson, M., Sanchez, P., \& Zheng, C. (2015). The impact of an integrated nursing handover system on nurses' satisfaction and work practices. J Clin Nurs., 25, 257-68. 
16. Joint commision report. (2020). Sentinel Event Alert 58:Inadequate hand-off communication. https://www.jointcommission.org/resources/patient-safety. Erişim tarihi: 15.02 .2020 .

17. Jeffs, L., Cardoso, R., Beswick, S., Acott, A., Simpson, E., Campbell, H., Lo, J., \& Ferris, E. (2013). Enablers and barriers to implementing bedside reporting: insights from nurses. Nurs Leadersh, 26, 39-52.

18. Sherman, J., Sand-Jecklin, K., \& Johnson, J. (2013). Investigating bedside nursing report: a synthesis of the literature. Medsurg Nurs., 22(5), 308-12, 318.

19. Lu, S., Kerr, D., \& McKinlay, L. (2014). Bedside nursing handover: patients' opinions. Int J Nurs Pract., 20, 451-459.

20. Manser, T., \& Foster, S. (2011). Effective Handover Communication: An Overview of Research and İmprovement. Efforts. Best Practice \& Research Clinical Anaesthesiology, 25, 181-191.

21. Maxson, P.M., Derby,K.M., \& Wrobleski, D.M. (2012). Bedside nurse-tonurse handoff promotes patient safety. Medsurg Nurs., 21(3), 140-4.

22. Wakefield, D.S., Ragan, R., Brandt, J., \& Tregnago, M. (2012). Making the transition to nursing bedside shift reports. Jt Comm J Qual Patient Saf., 38(6), 243-53.

23. Radtke, K., (2013). Improving patient satisfaction with nursing communication using bedside shift report. Clin Nurse Spec., 27(1), 19-25.

24. O'Connell B, \& Penney W. (2001). Challenging the handover ritual: recommendations for research and practice. Collegian, 8(3):14-8.

25. Davies, S. \& Priestley MJ. (2006). A reflective evaluation of patient handover practices. Nurs Stand., 20(21), 49-52.

26. Sağlık Bakanlığı Performans. Hastane hizmet kalite standartları 2011. https://dosyamerkez.saglik.gov.tr/Eklenti/2631,hkskitappdf.pdf?0 (Erişim Tarihi: 04.04.2020).

27. Tuğrul, E., \& Khorshid, L., (2015). Hemşirelerin önemli işlevlerinden biri: hasta teslimi. Ege Üniversitesi Hemşirelik Fakültesi Dergisi, 31(1), 95- 107.

28. Alvarado, K., Lee, R., Christoffersen, E., Fram, N., Boblin, S., Poole, N., \& et al. (2006). Transfer of accountability: transforming shift handover to enhance patient safety. Healtcare Quarterly, 9, 75-9.

29. Mosher, C. \& Bontomasi, R. (1996). How to improve your shift report. The American Journal of Nursing, 96(8), 32-4.

30. Sert, H., İlhan P., \& Okçu, P. (2019). Erişkin yoğun bakımda çalışan hemşirlerin yatak başı hasta teslimlerinin incelenmesi: standardize edilmiş bir form gerekli mi? Hemşire görüşleri. Yoğun bakım hemşireliği dergisi, 23(3), 160-167.

31. Collins, S.A., Stein, D.M., Vawdrey, D.K., Stetson, P.D., \& Bakken, S. (2011). Content overlap in nurse and physician handoff artifacts and the potential role of electronic health records: a systematic review. Journal of Biomedical Informatics, 44(4), 704-12.

32. Heidarizadeh, K., Rassouli, M., Manoochehri, H., Tafreshi, M.Z., \& Ghorbanpour, R.K.(2017). Effect of electronic report writing on the quality of nursing report recording. Electron Physician, 9(10), 5439-5445.

33. Johnson, M., Jefferies, D., \& Nicholls, D.(2012). Developing a minimum data set for electronic nursing handover. Journal of Clinical Nursing, 21(3- 4), 331-43.

34. Welsh, C.A., Flanagan, M.E., \& Ebright, P. (2010). Barriers and facilitators to nursing handoffs: recommendations for redesign. Nursing Outlook, 58(3), 148-54.

35. ACSQHC, Australian Commission on Safety and Quality in Health Care. Ossie Guide to Clinical Handover 2009. http://www. safetyandquality.gov.au/our-work/clinicalcommunications/ clinicalhandover. Erişim Tarihi: 10.11.2019. 